\title{
Brain \& Chiasmal Herniations into Sella after Medical Treatment of Prolactinoma
}

\author{
M.H. Bangash, D.B. Clarke, R.O. Holness
}

\begin{abstract}
Background: Dopamine agonists are widely used in the treatment of pituitary prolactinomas. We report a case of inferior mesial frontal lobe (gyrus rectus) and chiasmal herniations into an enlarged sella following successful medical treatment of a pituitary macroadenoma. Method: A 71-year-old healthy man presented to medical attention with visual complaints. On examination, he was found to have bitemporal hemianopsia. Endocrine evaluation revealed an elevated prolactin level. He was treated medically with a dopamine agonist (bromocriptine). Results: Evaluation after one year of medical treatment revealed stabilization of the patient's vision, with a significant bitemporal field loss. Serum prolactin levels normalized $(5.16 \mathrm{ng} / \mathrm{ml})$. The MRI of the sella showed almost complete disappearance of the tumor, resulting in right mesial frontal lobe herniation inferiorly into an enlarged sella with associated chiasmal deformation. Conclusions: We report a case where successful medical treatment of a large pituitary prolactinoma has resulted in inferior frontal lobe and chiasmal herniatons into an enlarged sella.
\end{abstract}

RÉSUMÉ: Hernie du cerveau et du chiasma dans la selle turcique suite au traitement médical d'un prolactinome. Contexte: Les agonistes de la dopamine sont largement utilisés dans le traitement des prolactinomes pituitaires. Nous rapportons un cas d'hernie du lobe frontal mésial inférieur (gyrus rectus) et du chiasma dans une selle turcique agrandie suite à la régression d'un macroadénome pituitaire traité médicalement avec succès. Méthode: Un homme âgé de 71 ans, en bonne santé, a consulté pour des troubles visuels. À l'examen on a noté une hémianopsie bitemporale. L'évaluation endocrinienne a montré un niveau élevé de prolactine. Il a été traité médicalement par un agoniste de la dopamine, la bromocriptine. Résultats: Après un an de traitement, la vision du patient était stable, mais il accusait une perte importante au niveau des champs visuels temporaux. Le niveau sérique de prolactine était normal, soit de 5,16 ng/mL. À l'IRM de la selle turcique, la tumeur avait presque complètement disparu entraînant une hernie de la partie mésiale droite du lobe frontal vers le bas associée à une déformation du chiasma dans une selle turcique agrandie. Conclusions: Nous rapportons l'observation d'un patient porteur d'un gros prolactinome pituitaire traité médicalement avec succès entraînant une hernie du lobe frontal inférieur et du chiasma dans une selle turcique agrandie.

Can. J. Neurol. Sci. 2006; 33: 240-242

Prolactinomas, the most common hormonally active pituitary adenomas, are usually detected as microadenomas $(<10 \mathrm{~mm}$ in diameter) and generally have a benign natural history. ${ }^{1}$ In contrast, macroprolactinomas (> 10mm diameter) may pose a greater clinical challenge since patients often present with symptoms related to mass effect. We report a case of inferior mesial frontal lobe and chiasmal herniations into an enlarged sella, as a consequence of successful medical treatment of a pituitary macroprolactinoma.

\section{Case History}

A 71-year-old man presented to medical attention complaining of visual disturbance. His neurological examination was remarkable for a bitemporal hemianopsia. Endocrine evaluation revealed a high prolactin level $(200 \mathrm{ng} / \mathrm{ml}$, normal $<25$ $\mathrm{ng} / \mathrm{ml}$ ) and imaging studies at that time showed a pituitary macroadenoma (the initial CT scan was destroyed and was therefore not available for review). He was treated medically with a dopamine agonist (bromocriptine, increased to $5 \mathrm{mg}$ tid). He responded well with slight improvement, then stabilization of

From the Department of Surgery (Neurosurgery), Dalhousie University, Halifax, Nova Scotia, Canada.

RECEIVED MARCh 18, 2005. ACCEPTED IN FINAL FORM JANUARY 10, 2006. Reprint requests to: David B. Clarke, QEII Health Sciences Centre - Halifax Infirmary, Room 3807, 1796 Summer Street, Halifax, Nova Scotia, B3H 3A7, Canada. 
his bitemporal visual field defect within the first few months of treatment.

After one year of treatment, routine visual field testing revealed no further deterioration of his visual field defect. Neuroimaging was performed by CT scan which showed a mass in the pituitary fossa different in character from the original pituitary tumor (more hypodense). Subsequent MRI of the sella demonstrated that the original tumor had all but disappeared. The intrasellar mass seen on the follow-up CT scan was, in fact, the infero-medial portion of the right frontal lobe that had herniated inferiorly into the sella, enlarged and vacated by the treated tumor. There was associated chiasmal deformation into the sella as well.

The patient has continued to be treated medically. His vision has remained stable and his serum prolactin levels have normalized. He is not able to arrange transportation for regular imaging studies and, therefore, is followed clinically and by a combination of visual field testing and serum prolactin levels.

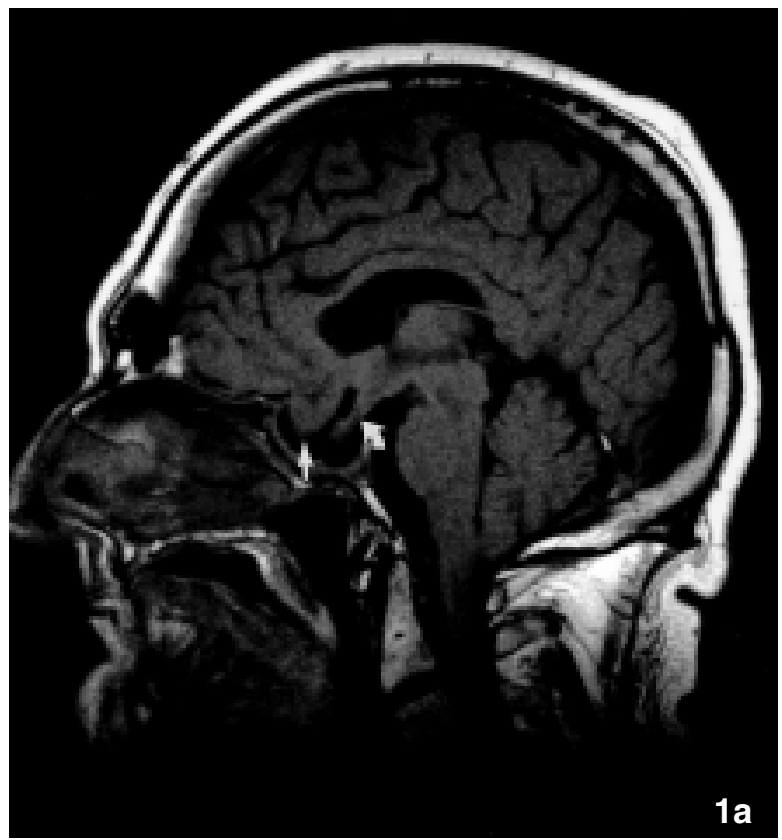

Figure 1: Post-treatment T1-weighted MRI. A. Mid-sagittal image demonstrates that the posterior aspect of the gyrus rectus (arrow) as well as the optic chiasm posteriorly (curved arrow) are seen within the sella. Residual tumor lines the margins of the expanded sella. B. Coronal view shows inferior displacement of frontal lobe (right gyrus rectus; arrow) into an enlarged sella.

\section{DISCUSSION}

The pituitary gland is a bilobed structure weighing approximately $0.6 \mathrm{~g}$ and is found within the confines of the sella turcica (pituitary fossa). The anatomy of the sella and sellar region has been recently detailed by Rhoton et al. ${ }^{2}$ The normal dimensions of the sella are approximately $13 \mathrm{~mm}$ in depth, 14 $\mathrm{mm}$ in width and $17 \mathrm{~mm}$ in length. The sella is bounded anteriorly by the tubeculum sellae, posteriorly by the dorsum sellae and laterally by the carotid prominences and cavernous sinuses. The floor of the sella is formed by a thin piece of

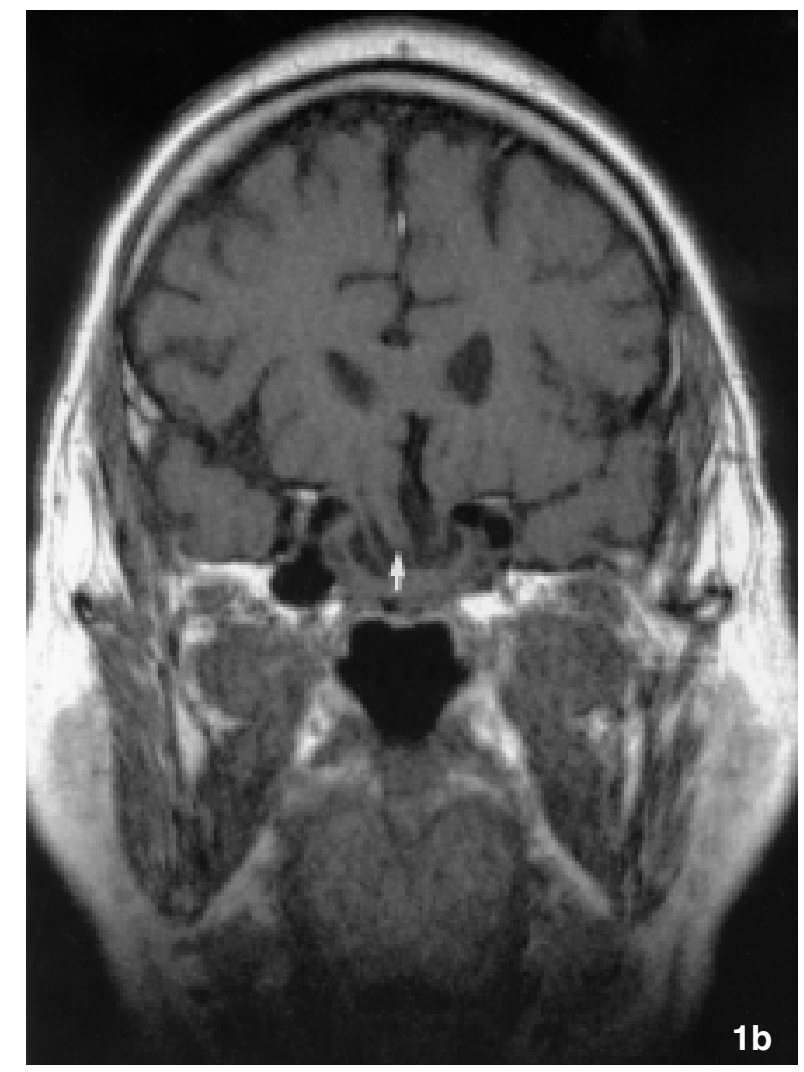

sphenoid bone which separates the sella from the underlying sphenoid sinus. The roof of the sella turcica is formed by a thin layer of dura, the diaphragma sellae, which covers the pituitary gland except for a small opening in its center that transmits the pituitary stalk.

Tumors of the anterior pituitary account for $10 \%$ to $15 \%$ of all primary brain tumors. ${ }^{3}$ Most patients with prolactinomas present having microadenomas, where high serum prolactin levels account for the clinical presentation of amenorrhea and/or galactorrhea in women, or decreased libido and impotence in men. Macroprolactinomas are less common and can cause symptoms related to extension superiorly involving the optic 
carotid artery, sphenoid sinus and suprasellar cistern. The MRI examination in the sagittal plane is useful to assess midline structures. The ability to distinguish normal pituitary from pituitary lesions is enhanced by the intravenous administration of paramagnetic contrast material. An MRI can also be useful in detecting hemorrhage within the pituitary gland. Subacute hemorrhage is seen as increased intensity on uncontrasted T1 images due to the presence of methemoglobin. Acute hemorrhage, as seen in cases of pituitary apoplexy, is appreciated as hypointensity on T2-weighted spin-echo or gradient echo sequences due to the presence of deoxyhemoglobin.

Dopamine agonists are widely used in the treatment of pituitary prolactinomas (reviewed by Nomikos, Buchfelder and Fahlbusch $^{5}$ ) and act directly on D2 dopamine receptors of normal and tumorous prolactin secreting cells ${ }^{6}$ (recently reviewed by Ivan, et al. $^{7}$ ). Side effects of dopamine agonist treatment can include nausea and vomiting, orthostatic hypotension, nasal congestion, peripheral vascular changes, ${ }^{6}$ depression, and nightmares. ${ }^{8}$ Chiasmal herniation $^{9-12}$ and even cerebrospinal fluid leakage ${ }^{13,14}$ into the sella vacated by a receding tumor have been reported previously. Furthermore, Gros and Cazaban ${ }^{15}$ in the pre-CT/MRI imaging era were the first to report the possibility of cerebral herniation into the intrasellar compartment, occurring after radiation treatment of acromegaly. The present case report is the first radiographic demonstration of herniation of the inferior mesial frontal lobe into the sella, resulting from successful dopamine agonist treatment of a macroprolactinoma.

Modern-day management of prolactinomas is primarily medical (reviewed by Nomikos, Buchfelder and Fahlbusch ${ }^{5}$ ), although surgical treatment has a role in patients with acutely deteriorating vision and possibly in primary treatment of some microprolactinomas. ${ }^{16,17}$ In our case, where there was no evidence of further visual deterioration, we have elected to continue to treat the patient medically.

The mechanism by which the inferior mesial frontal lobe herniates into the emptied sella is speculative and may be multifactorial. The size of the opening through the diaphragma varies between individuals ${ }^{2}$ and the dura of the diaphragma may be very thin. ${ }^{18}$ These conditions may be further exacerbated by expansion of a pituitary macroadenoma such that, following its reduction in size by treatment, the overlying neural structures are able to herniate into the sella. In addition, it has been postulated that the diaphragma sella may be more susceptible to erosion following radiation therapy. ${ }^{19}$ Although chiasmal herniation into the sella is well recognized, imaging showing herniation of the mesial frontal lobe has not been previously reported. In our case, we speculate that boney erosion of the planum sphenoidale by the expanding tumor, possibly in association with dural erosion, were important in allowing the frontal lobe's gyrus rectus to herniate inferiorly into the sella.

\section{REFERENCES}

1. Abraham P, Bevan JS. Prolactinoma. In: Powell MP, Lightman SL, Laws Jr. ER, editors. Management of pituitary tumors: The clinician's practical guide. Totowa: Humana Press; 2003: p.21-41.

2. Rhoton AL, Jr. The sellar region. Neurosurgery. 2002; 51(4 Suppl):S335-74.

3. Kovacs K, Horvath E. Tumors of the Pituitary Gland. Atlas of Tumor Pathology, fascicle 21, 2nd series. Washington, D.C.: Armed Forces Institute of Pathology, 1986: 1-269.

4. Tarr RW, Lewin JS. Optimization of magnetic resonance imaging for sellar lesions. Techniques in Neurosurgery. 2000; 6(4):25865.

5. Nomikos P, Buchfelder M, Fahlbusch R. Current management of prolactinomas. J Neurooncol. 2001; 54(2):139-50.

6. Molitch ME, Elton RL, Blackwell RE, Caldwell B, Chang RJ, Jaffe $\mathrm{R}$, et al. Bromocriptine as primary therapy for prolactin-secreting macroadenomas: results of a prospective multicenter study. J Clin Endocrinol Metab. 1985; 60(4):698-705.

7. Ivan G, Szigeti-Csucs N, Olah M, Nagy GM, Goth MI. Treatment of pituitary tumors: dopamine agonists. Endocrine. 2005; 28(1):101-10.

8. Turner TH, Cookson JC, Wass JA, Drury PL, Price PA, Besser GM. Psychotic reactions during treatment of pituitary tumours with dopamine agonists. $\mathrm{Br}$ Med J. (Clin Res Ed) 1984; 289(6452):1101-3.

9. Kaufman B, Tomsak RL, Kaufman BA, Arafah BU, Bellon EM, Selman WR, et al. Herniation of the suprasellar visual system and third ventricle into empty sellae: morphologic and clinical considerations. Am J Roentgenol. 1989; 152(3):597-608.

10. Lundin $\mathrm{P}$, Bergstrom $\mathrm{K}$, Nyman R, Lundberg PO, Muhr C. Macroprolactinomas: serial MR imaging in long-term bromocriptine therapy. Am J Neuroradiol. 1992; 13(5):1279-91.

11. Taxel P, Waitzman DM, Harrington JF, Jr., Fagan RH, Rothfield NF, Chen $\mathrm{HH}$, et al. Chiasmal herniation as a complication of bromocriptine therapy. J Neuroophthalmol. 1996; 16(4):252-7.

12. Jones SE, James RA, Hall K, Kendall-Taylor P. Optic chiasmal herniation--an under recognized complication of dopamine agonist therapy for macroprolactinoma. Clin Endocrinol (Oxf). 2000; 53(4):529-34.

13. Ommaya AK, Di Chiro G, Baldwin M, Pennybacker JB. Nontraumatic cerebrospinal fluid rhinorrhoea. J Neurol Neurosurg Psychiatry. 1968; 31(3):214-25.

14. Holness RO, Shlossberg AH, Heffernan LP. Cerebrospinal fluid rhinorrhea caused by bromocriptine therapy of prolactinoma. Neurology. 1984; 34(1):111-3.

15. Gros C, Cazaban R. Intrasellar cerebral hernia after prolonged radiotherapy of acromegaly. Montp Med. 1950; 37-38(5):397-99.

16. Wolfsberger S, Czech T, Vierhapper H, Benavente R, Knosp E. Microprolactinomas in males treated by transsphenoidal surgery. Acta Neurochir (Wien). 2003; 145(11):935-40.

17. Losa M, Mortini P, Barzaghi R, Gioia L, Giovanelli M. Surgical treatment of prolactin-secreting pituitary adenomas: early results and long-term outcome. J Clin Endocrinol Metab. 2002; 87(7):3180-6.

18. Renn WH, Rhoton AL, Jr. Microsurgical anatomy of the sellar region. J Neurosurg. 1975; 43(3):288-98.

19. Keyaki A, Makita Y, Nabeshima S, Motomochi M, Itagaki T, Tei T. Secondary empty sella syndrome: report of three cases and review of the literature. No Shinkei Geka. 1982; 10(11):1189-94. 